\title{
Siberian Newspapers of the Russian Empire and USSR Periods Issues of Conservation, Digitization, and Scientific Use
}

\author{
VIACHESLAV SHEVTSOV
}

\begin{abstract}
This report reflects the work that leading academic libraries in Siberia (in Tomsk, Irkutsk, and Krasnoyarsk) have been conducting over the past ten years on digitization of Siberian newspapers published between 1857 and 1991. These newspapers are valuable and often unique sources for the history, ethnography, economy, and everyday life of the Siberian people. Creating a comprehensive and common free-access database of Siberian newspapers promotes their preservation for current and future researchers, introduces them to scientific use. The report contains brief data on already digitized newspapers and on electronic sources where these newspapers can be found. The report shows the challenges, perspectives, and achievements of digitization, as well as possible ways of systematization, search for information and analysis of a large set of various newspaper texts.
\end{abstract}

Keywords: bibliographical index, digitization, Elektronnaia Sibir' ethnography, history, local community, open access, scientific libraries of Siberia, 1857-1991, Siberia

$\mathrm{T}$ he history of Siberian newspapers, as in many Russian provinces, starts with provincial broadsheets (vedomosti). In Siberia, they were launched for the first time in 1857, 20 years later than in the European part of the country. Provincial broadsheets were published in provincial centers-in Tobol'sk, Irkutsk, Krasnoiarsk, and Tomsk. Back then, Tomsk province included such parts of modern Russia as Tomsk and Novosibirsk oblasts and Altai krai. Provincial broadsheets had official 
and non-official parts. The official part consisted of decrees from the central and local authorities on various aspects of the administrative, social, and economic life of the province. The materials in the nonofficial part were created by the efforts of the "educated minority" in Siberia: clerks, gymnasium teachers, priests, doctors, a few merchants (that were different from the image of "Siberian merchant Kondrat"). Provincial broadsheets went beyond the government-approved program and published material about the history, geography, ethnography, economy, education and enlightenment, medicine and social life in Siberia. It was in provincial broadsheets that many unique archive documents and ethnographic descriptions were published. In Siberia privately owned periodicals that had a liberal tone and stood in opposition to the authorities emerged in the 1870-1880s. The newspapers Sibir' (Siberia), published in Irkutsk from 1873 to 1887, and Sibirskaia gazeta (Siberian newspaper), founded in 1881 in Tomsk by enlightener Piotr Makushin and closed by censorship in 1888, were examples of provincial broadsheets. In 1882 the Siberian regionalist Nikolai Yadrintsev founded the political and literary newspaper Vostochnoe obozrenie (Eastern review) in St. Petersburg (in 1888 it was moved to Irkutsk and in 1906 was closed by the censor). Sibirskaia zhizn' (Siberian life) was one of the most authoritative newspapers in Siberia at the beginning of the twentieth century; it was closed by Bolsheviks in 1919. During the Soviet period, the Bolshevik Party dominated Siberia's newspaper production. Among them were Sovietskaia Sibir' (Soviet Siberia) and Sel'skaia pravda (Rural truth) in Novosibirsk, Krasnoe znamia (The Red flag) in Tomsk, Altaiskaia pravda (Altai truth) in Barnaul, Vostochno-Sibirskaia pravda (Eastern Siberian truth) in Irkutsk and others. Their main task was to distribute political propaganda and ideologically influence citizens during the "building of socialism" in the USSR.

Newspapers and magazines of the period of the Russian empire are spread among different libraries and archives in the Russian Federation. The level of their completeness and integrity may greatly vary as they are printed on low-quality and fragile paper, which is often damaged. Some of the newspapers from the second half of the nineteenth century may be inaccessible due to their decrepit state. For example, by 2007 the disintegration of some Siberian newspapers in the Scientific Library of Tomsk State University reached 30 percent, and for the most popular issues 50 percent. ${ }^{1}$ The National Library of Russia in Saint Petersburg (before 1917 known as the Imperial Public Library) ${ }^{2}$ and the Russian State Library (in 1925-1991 known as the V.I. Lenin State Library of the USSR), ${ }^{3}$ which received legal deposits of all periodicals, 
hold some of the most complete collections. However, these libraries are digitizing only central and frequently requested periodicals, and digital copies of provincial newspapers can be created only as a paid service at individual request. Keen demand for pre-revolutionary and Soviet newspapers among Siberian researchers, educators, students, post-graduate students, journalists, and museum employees have encouraged regional libraries to take the lead in the process of the digitization of newspaper. They are supported and helped by the initiative of groups of researchers, local history experts, and librarians. This process started at different times and at first there was a very weak connection between its participants. At the Scientific Library of Tomsk State University digitization of newspapers started in 2004, at Novosibirsk State Scientific Library-in 2005, at Irkutsk State Scientific Library-in 2007, at Krasnoiarsk Krai State Scientific Library—in 2012. Large format scanners, large-capacity data storage devices for storing digital copies, server stations for fast and smooth data transfer could not be purchased immediately, so these issues had to be solved gradually. Teaching the library staff how to use the equipment and finding financial support for this painstaking work were challenging too. "Electronnaia Sibir'" (Electronic Siberia) project is supposed to help solve these problems. It was started in 2010 under a grant from the president of the Russian Federation as part of the program to support cultural and artistic creative projects of All-Russian importance. ${ }^{4}$ The project aims to integrate Siberian digital resources to enhance their usage for scientific, educational, and cultural purposes. Under the project, work in the digitization of Siberian newspapers that is being coordinated by four central libraries in Kemerovo, Novosibirsk, Tomsk regions and Altai Krai. Each library-project member is a creator, holder, and disseminator of its part of the electronic library and has the right to define the policy, speed, and specifics of transforming their holdings into digital form. Libraries are constantly collaborating in enriching their funds via a mutual exchange of digitized publications.

Digitization was chosen as a way to convert newspapers into electronic form instead of the established method of micrography because digital copy has higher quality, does not deteriorate, and is easy to store, to replicate, and to transmit over the Internet. Unlike working with micrographic copy, working with digital copies does not require any additional equipment. Collections of newspapers for every year (as a whole or page-by-page) are converted into $\mathrm{Dj} V u$ (black and white image), PDF or JPEG (color image) formats. These formats are chosen because they allow images of a smaller size but better quality. Simul- 
taneously misnumbered pages or newspaper issues and lacunae in newspaper pages can be found, empty page borders can be cut off and or misshapen lines of text can be fixed. After images have been processed and posted on the library's website, originals are no longer given to visitors to the reading hall and newspapers are placed in microclimatic containers. Thus, many users have access to newspaper funds while the original newspapers are preserved for future generations.

The digitization process is mostly conducted by Siberian libraries' regular staff members who possess a professional education and the required training in this field. Occasionally they are helped by narrowly focused specialist-technicians, programmers, and IT administrators. Libraries deliberately refused to make use of volunteers or crowd sourcing methods. In the first case, frequently changing volunteers would need at least some initial training, moreover, organizing their access to rare newspapers collections would be an issue. Using crowdsourcing methods would create the need to re-check and edit digitized pages, some of which can be done on amateur equipment.

The project has made available to users, both on the libraries' websites and through remote access, a number of features such as a chronologically ordered list of digitized newspapers, bibliographical descriptions of newspaper originals, any page from any newspaper issues, as well as the option to copy and download needed issues to the user's computer. Since each library does not possess every newspaper issue, URLs direct users to the website of a library where missing issues are stored. The Novosibirsk State Scientific Library provides an opportunity to search for separate words on the pages of some issues but because of the peculiarities of pre-revolutionary font such searches cannot be 100 percent effective and do not eliminate the need to examine the newspaper de visu. For creating full-text search, the Irkutsk Regional Scientific Library has chosen a method of full-text recognition, which is followed by proof reading of a text and comparing of it with the original. As a result, in 2008 the first two years (1857-1858) of "Irkutsk provincial broadsheets" issues were released on CD-disk. ${ }^{5}$

The Tomsk State University Scientific Library possesses one of the largest collections of Siberian and Far Eastern newspapers, which includes 1,318 items. ${ }^{6}$ By now users have access to 40 newspapers from the library's website. ${ }^{7}$ Among them are such major periodicals as Tomskie gubernskie vedomosti (Tomsk provincial broadsheets), Tomskie eparkhial'nye vedomosti (Tomsk diocesan broadsheets), Sibirskii vestnik (Siberian journal), Vostochnoe obozrenie (Eastern review), Sibirskaia zhizn' (Siberian life); newspapers from the Revolutionary era and the Russian 
Civil War such as Golos svobody" (Voice of freedom), Svobodnaia Sibir' (Free Siberia), Nadezhda Rossii (Hope of Russia), Golos Sibirskoi armii (Voice of the Siberian army), Znamia revoliutsii (Flag of the revolution), and Soviet newspapers, for example, Krasnoe znamia (The red flag), Kolkhoznik, Altai kolkhoznik, Stalinets. The Tomsk Regional Universal Scientific Library published issues of "Tomsk diocesan broadsheets" 8 on its website. As "Tomsk provincial broadsheets" this local church official newspaper contained official and non-official parts.

The pre-revolutionary periodicals collection, stored in the State Universal Research Library of Krasnoiarsk krai, has more than 12,000 newspaper and magazine pages-Enisejskie eparhial'nye vedomosti (Yenisei diocesan broadsheets), Eniseiskaia mysl' (Enisei thought), Sibirskie voprosy (Siberian issues), Sibirkie zapiski (Siberian notes), Sibirskaia derevnia (Siberian village), and Spravochnik Vostochno-Sibirskogo obshhestva sel'skogo khoziaistva, promyshlennosti, torgovli v Enisejskoj gubernii (The digest of Siberian society of agriculture, industry and trade in Enisei province). ${ }^{9}$ The library collaborates with the the State Archive of Krasnoyarsk Krai to digitize Krasnoiarski rabochii (Krasnoiarsk worker), one the first Soviet newspapers in Krasnoiarsk.

The Novosibirsk State Scientific Library's website hosts eight digitized newspapers. ${ }^{10}$ Among them are incomplete sets of the pre-revolutionary newspapers Tomskie gubernskie vedomosti (Tomsk provincial broadsheets), Obskaia zhizn' (Ob life), Sibirskaia gazeta (Siberian newspaper), Sibirskii zhurnal (Siberian Journal), Sibirskii listok (Siberian leaflet), and Tomskii listok (Tomsk leaflet). Of particular value is Sovetskaia Sibir' (Soviet Siberia) a newspaper that was an official organ of Soviet authorities in the Siberian oblast' and Novosibirsk oblast'. Through this newspaper it is possible to trace such important historical processes as collectivization, industrialization, political repressions, migration to Siberia, and Siberia's role in the Great Patriotic War. The project "Elektronnaia Sibir"' shows visitor statistics broken down by countries and cities. As of December 2015, the electronic archive has been viewed 34,980 times from the various cities across the Russian Federation (from Moscow-14,649 times, from Novosibirsk—7,389 times, from Perm'1,560 times, from Barnaul-1,324 times, from St. Petersburg-1,247 times, from Tomsk-710 times). Among foreign countries, it is most frequently visited from the United States-10,258 times, specifically from Mountain View, California-8,868). The United States is followed by Ukraine (1,176 visits), Germany (698 visits), Israel (293 visits), the Czech Republic (260 visits), Belarus (170 visits), China (145 visits), Latvia (135 visits), and the United Kingdom (131 visits). ${ }^{11}$ 
The Altai Krai Universal Scientific Library digitized such transregional small-circulation newspapers as Zhizn' Sibiri (Life of Siberia), Communard, Kommunisitcheskaia iacheika (A Communistic cell), and Statistika Sibiri" (Statistics of Siberia). Among pre-revolutionary periodicals there are Sibirskie voprosy (Siberian issues) and Voprosy kolonizatsii (Issues of colonization). ${ }^{12}$ Seventeen small-circulation newspapers from various districts of the Kemerovo region from the period of industrialization of the 1930s are represented on the website of Kemerovo Regional Scientific Library. These are newspapers such as Leninskii put' (Lenin's way), Stalinski put' (Stalin's way), and Sotsialisticheskaia stroika"(Socialist construction). ${ }^{13}$ It is interesting that these resources have been most frequently viewed from the United States (48,185 views), while from Russia they have been visited 4,251 times.

The second important collection (after the collection of the Tomsk State University Scientific Library) is stored in the Irkutsk State Universal Scientific Library. In 2008 the Library opened a website titled "Pre-revolutionary periodicals of Irkutsk province" where various official and privately owned newspapers, mainly from Eastern Siberia from 1857 to 1916 , have been stored. ${ }^{14}$

In 2011, the Irkutsk regional branch of the Communist Party of the Russian Federation and the mobile telecom operator "Baikalmestkom" helped the Library purchase new equipment. This allowed for the digitization of more newspapers and an increase in the stability of the library's server. The site was enlarged and received a new title Khroniki Priangar'ia (Chronicles of Priangar'e). It contains 118 periodicals and 63,711 digital files. ${ }^{15}$

When working with electronic collections of Siberian newspapers, users need to either quickly scan the contents of a periodical or thoroughly analyze an extensive array of thematically diverse texts. This task can be solved with the help of an index of newspaper's articles. An index has been created of articles from the non-official part of the "Tomsk provincial broadsheets" for the whole period of its publication, from 1857 to 1917. The index includes more than 10,000 articles. ${ }^{16}$

Half of the articles that have the highest value are published in the "Tomsk, Tomsk Province, Siberia" section-4,929 items. They are divided into eight themes and sub-themes. If a single article includes information on history, ethnography, geography, medicine, and so on, it is attributed to one of the themes depending on article's main subject, its aim, the value of the information in it, and the author's professional background. The index also contains author information-the author's last name and initials, pen name, and cryptonym or source of bor- 
rowing. The title of an article is provided as it was published in the newspaper with brief explanatory text when needed. The themes are as follows:

1. History: the city of Tomsk, Tomsk province, other Siberian cities; inclusion and assimilation (osvoenie) of Siberia and the Far East; inclusion of the Middle Asia; historical documents; administration, self-administration (samoupravlenie) and legal proceedings in Siberia; city's self-administration; notable people in the history of Siberia; Siberian bibliography; conscription.

2. Ethnography: indigenous population of Siberia; Russian population of Siberia; collection of ethnographical information.

3. Economy: gold mining industry; measures, weights, horometry; routes of communication; agriculture; resettlement to Siberia and Far East; flour producing; butter manufacture; animal breeding; forest lands; alcohol distillation and sale; tobacco production; sugar production; salt production; glassmaking; stationery industry; hunting; fishing; beekeeping; trade; finances; economical exhibitions.

4. Geography and nature of Siberia.

5. Spiritual, social and every-day life: periodicals; holidays, entertainment; morals; congratulations; celebration of 300th anniversary of Siberia's inclusion within Russia; visiting of Tomsk and Tomsk province by members of the Royal Family; clergymen's appeals to parishioners; charity; exile, criminality and prisons in Siberia; Siberia as a part of Russia; literary evenings; poetry; theater; urban land improvement; etc.

6. Education and enlightenment: elementary and secondary education; higher education; construction of Siberian university; female education; military educational institutions; spreading of literacy among citizens; libraries; museums; book stores; public lectures; self-education.

7. Health care and medicine: medical reports; pharmacies; doctor's social status; charity care in Tomsk; medical assistance to lowincome patients; obstetrics; infection control; medical education; therapeutic water and mud; anti-alcoholism; folk medicine; veterinary medicine; etc.

8. Housekeeping.

The program has been expanding over time, with three new sections added to the index: Revolution 1905-1907" (1,649 articles), "Across Russia" (2,318 articles), and "Abroad" (1,317 articles).

The creation of the digital collections of Siberian newspapers with free access for every user is one of the most important projects under- 
taken by the Siberian academic libraries. Issues of technical, financial, and staff provision have been solved. Now all participants are working toward creating a united virtual database of Siberian newspapers, which would bring together important and rare periodicals without gaps in issues or years. Digital format of newspapers allows preservation and safekeeping of the originals and gives Russian and foreign academics more opportunities to use them in their research. Despite the fact that these newspaper articles are now in public domain, in accordance with the policy of some libraries, digital copies of Siberian newspapers are available through restricted access only. For example, the holdings of the Tobolsk Regional Scientific Library ${ }^{17}$ grants users access only by using computer workstations located in the library's reading halls. Searching for information requires the creation of bibliographical indexes of articles from different newspapers, which is painstaking and laborious. Compiling an index of the non-official part of the "Tomsk provincial broadsheets" was auxiliary to the main research goal-to study the history of the genesis and development of provincial broadsheets in Siberia. This index can be used as a model for similar indexes but its improvement requires using specialized database software.

\begin{abstract}
Viacheslav Veniaminovich Shevtsov, $\mathrm{PhD}$, is professor at the Department of Russian History at Tomsk State University. He was one of the initiators of the digitization process of Siberian newspapers. He is the author of Tomskie gubernskie vedomosti (1857-1917) v sociokul'turnom $i$ informatsionnom prostranstve Sibiri (Tomsk Provincial Sheets (18571917) in Sociocultural and Information Space of Siberia (Tomsk: TSU, 2012)) and Pravitel'stvennaia periodicheskaia pechat' Sibiri (vtoraia polovina 19-nachalo 20 veka) (Governmental Periodicals in Siberia (the Second Half of the 19th Century and Beginning of the 20th Century) (Tomsk: TSU, 2016)). From 2013 to 2015 he participated in a Russian Federation Government Grant "Man in a Changing World. Problems of Identity and Social Adaptation in History and at Present."
\end{abstract}

\title{
Acknowledgments
}

This report was prepared as part of the research work of the TransSiberian Scientific Way research center at Tomsk State University, with financial support from the Russian State Scientific Fund, grant "Siberian periodicals of Tomsk province in the second half of 19th-the beginning 
of the 20th century in socio-political and cultural life of the region," project no. 16-11-70002.

\section{Notes}

1. O.V. Manernova, "Podlhody k sokhraneniiu kollektsii sibirskikh gazet v nauchnoi biblioteke Tomskogo gosudarstvennogo universiteta," in 150 let periodicheskoi pechati v Sibiri : materialy nauchnoi konferentsii, posviashchennoi 150-letiiu izdaniia v Sibiri "Gubernskikh vedomostei" (Tomsk, 19-20 aprelia 2007) (Tomsk: Izdatel'stvo TML-Press, 2007).

2. Gazety Rossii (1703-1917), Rossiiskaia natsional'naaa biblioteka, http:// www.nlr.ru/rlin/svnewsp.php (accessed 5 December 2015).

3. Fond gazet, Rossiiskaia gosudarstvennaia biblioteka, http://www.rsl. $\mathrm{ru} / \mathrm{ru} / \mathrm{s} 2 / \mathrm{d} 106$ (accessed 5 December 2015).

4. Elektronnaia Sibir', http://elib.ngonb.ru/jspui/ (accessed 5 December 2015).

5. Dorevoliutsionnaia periodicheskaia pechat' Irkutskoi gubernii, http:// irabis.irklib.ru/gaz/gaz_dvd.htm (accessed 5 December 2015).

6. Kollektsiia sibirskikh i dal'nevostochnykh gazet $\mathrm{v}$ fonde Nauchnoi biblioteki TGU, Nauchnaia biblioteka Tomskogo gosudarstvennogo universiteta (TGU), http://www.lib.tsu.ru/ru/kollekciya-sibirskih-i-dalnevostochnyhgazet-v-fonde-nauchnoy-biblioteki-tgu (accessed 5 December 2015).

7. Nauchnaia biblioteka TGU, Sibirskie gazety, http://vital.lib.tsu.ru/ vital/access/manager/Index?site_name $=\% \mathrm{D} 0 \% \mathrm{~A} 1 \% \mathrm{D} 0 \% \mathrm{~B} 8 \% \mathrm{D} 0 \% \mathrm{~B} 1 \% \mathrm{D} 0 \%$ B8\%D1\%80\%D1\%8C.\%20\%D0\%A2\%D0\%BE\%D0\%BC\%D1\%81\%D0\%BA.\%20 $\% \mathrm{D} 0 \% \mathrm{~A} 2 \% \mathrm{D} 0 \% 93 \% \mathrm{D} 0 \% \mathrm{~A} 3$ (accessed 5 December 2015).

8. Tomskaia oblastnaia universal'naia nauchnaia biblioteka, Tomskie eparkhial'nye vedomosti, http://elib.ngonb.ru/jspui/handle/NGONB/15090 (accessed 5 December 2015).

9. Gosudarstvennaia universal'naia nauchnaia biblioteka Krasnoiarskogo kraia, Dorevoliutsionnye periodicheskie izdaniia, http://irbis.kraslib.ru/ cgi-bin/irbis64r/irbis64r_91/cgiirbis_64.exe?I21DBN=MER_VV\&P21DBN=M $E R \& Z 21 \mathrm{ID}=\& S 21 \mathrm{REF}=\& S 21 \mathrm{CNR}=\& S 21 \mathrm{STN}=1 \& S 21 \mathrm{FMT}=\mathrm{vv} \& \mathrm{C} 21 \mathrm{COM}=\mathrm{S} \& 2$ S21P02=0\&2_S21P03=I\%3D\&2_S21STR=D129273 (accessed 5 December 2015).

10. Novosibirskaia gosudarstvennaia oblastnaia nauchnaia biblioteka, Elektronnyi arkhiv starinnykh gazet, http://elib.ngonb.ru/jspui/handle/ NGONB/31 (accessed 5 December 2015).

11. Novosibirskaia gosudarstvennaia oblastnaia nauchnaia biblioteka, Statistika, http://elib.ngonb.ru/jspui/displaystats?handle=NGONB $\% 2 \mathrm{F3}$ $1 \&$ submit_simple $=\% \mathrm{D} 0 \% 9 \mathrm{~F} \% \mathrm{D} 1 \% 80 \% \mathrm{D} 0 \% \mathrm{BE} \% \mathrm{D} 1 \% 81 \% \mathrm{D} 0 \% \mathrm{BC} \% \mathrm{D} 0 \% \mathrm{BE} \% \mathrm{D} 1 \%$ $82 \% \mathrm{D} 1 \% 80+\% \mathrm{D} 1 \% 81 \% \mathrm{D} 1 \% 82 \% \mathrm{D} 0 \% \mathrm{~B} 0 \% \mathrm{D} 1 \% 82 \% \mathrm{D} 0 \% \mathrm{~B} 8 \% \mathrm{D} 1 \% 81 \% \mathrm{D} 1 \% 82 \% \mathrm{D} 0 \%$ B8\%D0\%BA\%D0\%B8 (accessed 5 December 2015). 
12. Altaiskaia kraevaia universal'naia nauchnaia biblioteka, Sibirika i kraevedenie (periodicheskie izdaniia), http://elib.ngonb.ru/jspui/handle/ NGONB/12916 (accessed 5 December 2015).

13. Kemerovskaia oblastnaia nauchnaia biblioteka, Periodicheskie izdaniia Kemerovskoi oblasti, http://elib.ngonb.ru/jspui/handle/NGONB/63 (accessed 5 December 2015).

14. Dorevoliutsionnaia periodicheskaia pechat' Irkutskoi gubernii v fondakh Irkutskoi oblastnoi gosudarstvennoi universal'noi nauchnoi biblioteki im. I.I. Molchanova-Sibirskogo, http://irabis.irklib.ru/gaz (accessed 5 December 2015).

15. Khroniki Priangar'ia, Periodicheskaia pechat' Irkutskoi oblasti dorevoliutsionnogo i sovetskogo periodov (1857-1997), http://www.irabis.irklib. ru/hronp (accessed 5 December 2015).

16. Tomskie gubernskie vedomosti, http://www.lib.tsu.ru/ru/gazeta-tomskiegubernskie-vedomosti (accessed 5 December 2015).

17. Fond periodicheskikh izdanii Tiumenskoi oblastnoi nauchnoi biblioteki, http://www.tonb.ru/resources/periodica.php (accessed 5 December 2015). 